\title{
APLICAÇÃO DE RESISTIVIDADE E POLARIZAÇÃO INDUZIDA NA INVESTIGAÇÃO DE OBJETOS ENTERRADOS EM SÍTIO CONTROLADO DO IAG/USP
}

\author{
Elizete M. Araújo da Silva \\ Orientador: Dr. Vagner Roberto Elis (IAG-USP) \\ 79 p - Dissertação (Mestrado) - Defesa 24.08.2004
}

\begin{abstract}
RESUMO. No Brasil, tem ocorrido uma grande concentração das populações em áreas urbanas, fato esse que intensificou o uso da subsuperfície, tanto pelas industrias, como também para a manutenção do conforto urbano. Dentro desse contexto, os métodos geofísicos de investigação tem conquistado espaço no ambiente urbano, devido à dificuldade em se aplicar métodos diretos. No entanto, os métodos geofísicos de ambigüidades inerentes às interpretações, diminuindo a sua aplicabilidade e confiabilidade. Sendo assim, a proposta desta pesquisa desenvolvida no município de São Paulo baseia-se na caracterização de alvos enterrados em uma área controlada de testes, contendo tambores metálicos e plásticos. Na pesquisa são utilizados os métodos da eletrorresistividade e polarização induzida com a finalidade de obter a assinatura geoelétrica dos alvos e testar novos programas de interpretação e de simulações numéricas. Foram realizadas simulações numéricas (procurando reproduzir as situações reais de campo) e foram utilizados processos de interpretação 2D (qualificativos e quantitativos) durante o tratamento dos dados obtidos nos levantamentos de campo, o que permitiu a caracterização das anomalias geradas pelos alvos bem como a definição do seu comportamento em subsuperfície de acordo com os parâmetros considerados para cada método. Por meio dos elevados valores de resistividade aparente foi possível identificar as posiç̧ões dos dois tipos de tambores, e os valores de cargabilidade permitiu distinguir os tambores metálicos dos tambores plásticos.
\end{abstract}

ABSTRACT. In Brazil, a great concentration of populations has occurred in urban areas, a fact that has intensified the use of the subsurface, as much because of the industries as also for the maintenance of the urban comfort. Inside this context, the geophysical methods of exploration have conquered space in the urban environment, due to the difficulty in applying direct methods. However, the geophysical methods are subject to ambiguities that are inherent to the interpretations, diminishing its applicability and trustworthiness. Thus, the proposal of this research developed in São Paulo City is based on the characterization of targets buried in a controlled area of tests, containing metallic and plastic drums. In the research, the methods of the electroresistivity and induced polarization are used to get the geoeletric signature of the targets and to test new programs of interpretation and numerical simulations. Numerical simulations were carried through (trying to reproduce the real situations) and processes of interpretation of 2D (qualitative and quantitative) were used during the treatment of the data gotten in the field surveys, what allowed the characterization of the anomalies generated for the targets as well as the definition of its behavior in subsurface according to the parameters considered for each method. Through the high values of apparent resistivity it was possible to identify the positions of the two types of drums, and the values of chargeability allowed to distinguish the metallic druns from the plastic drums. 